\title{
DAMPAK PARIWISATA TERHADAP PELUANG USAHA DAN KERJA LUAR PERTANIAN DI DAERAH PESISIR
}

\author{
Impact Tourism on Off Farm Business and Employment Opportunities in Coastal Area
}

\author{
Dian Widya Setiyanti ${ }^{*}$ dan Ir. Dwi Sadono, M.Si \\ Departemen Sains Komunikasi dan Pengembangan Masyarakat, Fakultas Ekologi Manusia, IPB \\ *)Email :dianws@yahoo.com
}

Diterima 4 Oktober 2011 / Disetujui 23 Novemeber 2011

\begin{abstract}
The tourism has a very significant role in national economic development. Social changes occured as a result of direct contacts from tourism in tourist areas. One of consequence from the tourism activities is emergence of businesses and employment opportunities which can encourage local economies. The purpose of this research was to identify business and employment opportunities as a result of tourism activities at Pramuka Island and also to identify characteristics of the community. Another purpose is to analyze level of income, linkages between agricultural sector and nonagriculture sector, and transfer of resources (land) that arise due to tourism activities. The research methods are qualitative method which supported by quantitative methods. The results showed that tourism activities in Pramuka island has created business and employment opportunities for local community. Opportunities are predominantly used by natives. Tourism businesses and employment tend to be main livelihood of local people although their income are still at low-income levels. Linkage between agriculture sector and nonagriculture sector in Pramuka Island is shown by the increasing demand in fisheries sector as raw material for some businesses. Transfer of resources tends to occur among natives and there is one policy that prohibits people to build a building around the island ring road.
\end{abstract}

Keywords : impact, tourism, business and employment opportunities.

\begin{abstract}
ABSTRAK
Pariwisata memiliki peran yang sangat penting dalam pembangunan ekonomi nasional. Perubahan-perubahan sosial terjadi sebagai hasil dari kontak langsung dari pariwisata di kawasan wisata. Salah satu konsekuensi dari kegiatan pariwisata adalah munculnya usaha dan kesempatan kerja yang dapat mendorong ekonomi lokal. Tujuan dari penelitian ini adalah untuk mengidentifikasi peluang usaha dan lapangan kerja sebagai akibat dari kegiatan pariwisata di Pulau Pramuka dan juga untuk mengidentifikasi karakteristik masyarakat. Tujuan lain adalah untuk menganalisis tingkat pendapatan, keterkaitan antara sektor pertanian dan sektor nonpertanian, dan transfer sumber daya (lahan) yang timbul akibat kegiatan pariwisata. Metode penelitian adalah metode kualitatif yang didukung oleh metode kuantitatif. Hasil penelitian menunjukkan bahwa kegiatan wisata di Pulau Pramuka telah menciptakan peluang usaha dan lapangan kerja bagi masyarakat setempat. Peluang yang banyak digunakan oleh penduduk asli. Bisnis dan bekerja di bidang pariwisata merupakan mata pencaharian utama masyarakat setempat, meskipun tingkat pendapatan mereka masih rendah. Keterkaitan antara sektor pertanian dan sektor nonpertanian di Pulau Pramuka ditunjukkan oleh meningkatnya permintaan di sektor perikanan sebagai bahan baku untuk beberapa bisnis. Transfer sumber daya cenderung terjadi antara pribumi dan ada satu kebijakan yang melarang orang untuk membangun gedung di sekitar jalan lingkar pulau.
\end{abstract}

Kata kunci: dampak, pariwisata, bisnis dan kesempatan kerja.

\section{PENDAHULUAN}

Keberadaan sektor pariwisata sebagai salah satu sektor andalan pembangunan perekonomian nasional, merupakan peran yang signifikan. Terjadinya penurunan pemasukan devisa dari sektor migas pada era 1980-1990an, mengakibatkan sektor pariwisata mulai diandalkan oleh negara sebagai sumber penghasilan lain di luar migas. Berbagai kebijakan mengenai pengembangan sektor pari- wisata pun telah banyak ditempuh oleh pemerintah, diantaranya melalui Undang-Undang Nomor 10 Tahun 2009 tentang Kepariwisataan Pasal 4, Rencana Pembangunan Nasional Jangka Pendek (RPJM) 2010-2014, dan Rencana Pembangunan Nasional Jangka Panjang (RPJP) 2009-2025. Beberapa organisasi inter-nasional seperti PBB, Bank Dunia dan World Tourism Organization (WTO) juga telah mengakui bahwa pariwisata merupakan bagian yang tidak terpisahkan dari 
kehidupan manusia terutama menyangkut kegiatan sosial dan ekonomi.

Seiring dengan berkembangnya pariwisata dan adanya kenaikan jumlah kunjungan wisatawan, telah membawa konsekuensi tersendiri khususnya pada daerah tujuan wisata dan masyarakat lokal. Kehadiran pariwisata pada dasarnya mampu mempercepat pertumbuhan ekonomi dan penyediaan lapangan kerja, meningkatkan penghasilan, meningkatkan standar hidup, serta menstimulasi sektor-sektor produktif lainnya (Pendit, 2006). Karyono (1997) menjelaskan bahwa tumbuhnya peluang usaha dan kerja akibat pariwisata menyebabkan permintaan terhadap tenaga kerja meningkat. Makin banyak wisatawan yang berkunjung maka makin banyak pula jenis usaha yang tumbuh di daerah wisata sehingga makin luas lapangan kerja yang tercipta. Lapangan kerja yang tercipta tidak hanya yang langsung berhubungan dengan pariwisata, tetapi juga di bidang yang tidak langsung berhubungan dengan pariwisata. Hal tersebut menunjukkan bahwa pariwisata mempunyai potensi yang besar dalam menyediakan lapangan kerja bagi para tenaga kerja yang membutuhkan lapangan kerja baru.

Pengembangan kawasan pesisir untuk keperluan rekreasi di Indonesia cenderung meningkat bersamaan dengan semakin digiatkannya bidang kepariwisataan. Salah satu kawasan pesisir di Indonesia adalah Kepulauan Seribu. Pulau Pramuka merupakan pulau berpenduduk di Kepulauan Seribu yang mulai berkembang menjadi daerah pariwisata beberapa tahun belakangan ini karena keindahan alam di sekitar pulau. Sebagai pusat pemerintahan Kepulauan Seribu, Pulau Pramuka memiliki fasilitasfasilitas yang lebih lengkap dibandingkan dengan pulaupulau di sekitarnya sehingga memiliki daya tarik tersendiri bagi wisatawan untuk datang ke pulau ini. Perubahan-perubahan dalam kehidupan sosial ekonomi masyarakat dapat terjadi sebagai akibat hadirnya sektor pariwisata di Pulau Pramuka. Adanya kegiatan pariwisata telah memunculkan suatu bentuk peluang usaha dan kerja di daerah ini. Potensi pariwisata dalam menyerap tenaga kerja terlihat pada bentuk-bentuk usaha, seperti penginapan, rumah makan, penyewaan alat snorkeling, dan lainlain. Oleh karena itu, peneliti tertarik untuk mengkaji lebih dalam lagi mengenai dampak pariwisata terhadap peluang usaha dan kerja luar pertanian yang muncul terutama pada daerah pesisir, seperti di Pulau Pramuka. Penelitian dampak pariwisata umumnya mengkaji dampak terhadap sosial ekonomi maupun sosial budaya, seperti dalam penelitian Wijaya (2007), Mardiyaningsih (2003), Swarsi et al. (1996), dan Windiyarti et al. (1994), serta melihat kontribusi sektor pariwisata terhadap pendapatan dan kesejahteraan masyarakat, seperti dalam penelitian Sulaksmi (2007), Minullah (1997), dan Sudirman (1991). Masih sedikit yang mengkaji dampak pariwisata dengan fokus pada peluang usaha dan kerja luar pertanian, diantaranya penelitian Sadono et al. (1992) dan Tando (1992).

\section{Rumusan Penelitian}

Berdasarkan latar belakang yang telah dipaparkan sebelumnya, maka secara spesifik masalah penelitian yang akan dikaji dalam penelitian adalah:

1. peluang usaha dan kerja apa saja yang tumbuh karena adanya kegiatan pariwisata di Pulau Pramuka dan bagaimana karakteristik masyarakat yang memanfaatkan peluang usaha dan kerja tersebut?

2. bagaimana pengaruh pemanfaatan peluang usaha dan kerja yang muncul karena adanya kegiatan pariwisata di Pulau Pramuka terhadap tingkat pendapatan?

3. sejauh mana terjalin keterkaitan antara sektor pertanian dengan luar pertanian di Pulau Pramuka dalam upaya memanfaatkan peluang usaha dan kerja yang muncul karena adanya kegiatan pariwisata?

4. sejauh mana telah terjadi alih sumber daya (dari milik penduduk lokal menjadi milik pendatang) dalam upaya memanfaatkan peluang usaha dan kerja yang muncul karena adanya kegiatan pariwisata?

\section{Tujuan Penelitian}

Berdasarkan perumusan masalah yang telah dipaparkan di atas, maka tujuan dilaksanakannya penelitian ini adalah mengetahui, mengidentifikasi dan menganalisis:

1. peluang usaha dan kerja yang tumbuh sebagai akibat adanya kegiatan pariwisata di Pulau Pramuka dan karakteristik masyarakat yang memanfaatkan peluang usaha dan kerja tersebut;

2. pengaruh pemanfaatan peluang usaha dan kerja yang muncul karena adanya kegiatan pariwisata di Pulau Pramuka terhadap tingkat pendapatan;

3. keterkaitan antara sektor pertanian dengan luar pertanian di Pulau Pramuka dalam upaya memanfaatkan peluang usaha dan kerja yang muncul karena adanya kegiatan pariwisata;

4. alih sumber daya (dari milik penduduk lokal menjadi milik pendatang) dalam upaya memanfaatkan peluang usaha dan kerja yang muncul karena adanya kegiatan pariwisata.

\section{Kegunaan Penelitian}

Berdasarkan rumusan masalah dan tujuan penelitian yang telah dipaparkan, maka kegunaan dari penelitian ini adalah:

1. bagi pihak pemerintah, penelitian ini diharapkan dapat digunakan sebagai literatur dan media evaluasi pemerintah dalam melakukan pengembangan dan pengelolaan pariwisata di daerah pesisir sehingga kebijakan pengembangan pariwisata tidak hanya untuk memperbesar perolehan devisa atau pendapatan daerah saja tapi juga dapat meningkatkan kehidupan sosial ekonomi masyarakat di Kepulauan Seribu khususnya di Pulau Pramuka;

2. bagi pihak akademisi, penelitian ini diharapkan dapat menambah literatur dan wawasan pengetahuan ter- 
utama pada bidang ilmu yang bersangkutan dengan penelitian pariwisata dan pesisir;

3. pihak masyarakat, penelitian ini diharapkan dapat menambah wawasan masyarakat mengenai dampak pariwisata terhadap peluang usaha dan kerja luar pertanian di daerah pesisir.

\section{PENDEKATAN TEORITIS}

\section{Tinjauan Pustaka}

\section{Konsep Pariwisata}

Menurut Yoeti (1996), bila ditinjau secara etimologi pariwisata berasal dari bahasa Sansekerta, yaitu "pari" dan "wisata". "Pari" berarti banyak, berkali- kali, dan "wisata" berarti perjalanan, bepergian. Bila didefinisikan, Yoeti (1996) menjelaskan bahwa pariwisata merupakan suatu perjalanan yang dilakukan untuk sementara waktu, yang diselenggarakan dari suatu tempat ke tempat lain, dengan maksud bukan untuk berusaha (berbisnis) atau mencari nafkah di tempat yang dikunjungi, tetapi sematamata untuk menikmati perjalanan tersebut guna bertamasya, dan rekreasi atau memenuhi keinginan yang beraneka ragam. Menurut Undang-Undang Nomor 9 Tahun 1990 dalam Musanef (1996), pariwisata adalah segala sesuatu yang berhubungan dengan wisata termasuk pengusahaan objek, daya tarik, dan usaha-usaha yang terkait di bidang ini. Pengertian ini mengandung lima unsur, yaitu 1) unsur manusia (wisatawan); 2) unsur kegiatan (perjalanan); 3) unsur motivasi (menikmati); 4) unsur sasaran (objek dan daya tarik wisata); dan 5) unsur usaha.

\section{Dampak Pariwisata}

Pariwisata merupakan suatu gejala sosial yang kompleks dan menyangkut manusia seutuhnya serta memiliki berbagai aspek, seperti sosiologis, psikologis, ekonomis, ekologis, dan lain-lain. Aspek yang mendapat perhatian yang paling besar dan hampir merupakan satu-satunya aspek yang dianggap penting adalah aspek ekonomi. Menurut Cohen (1984) dalam Pitana dan Gayatri (2004), dampak pariwisata terhadap kondisi ekonomi masyarakat lokal dapat dikategorikan menjadi delapan kelompok besar, yaitu 1) dampak terhadap penerimaan devisa; 2) dampak terhadap pendapatan masyarakat; 3) dampak terhadap kesempatan kerja; 4) dampak terhadap hargaharga; 5) dampak terhadap distribusi manfaat atau keuntungan; 6) dampak terhadap kepemilikan dan kontrol; 7) dampak terhadap pembangunan pada umumnya; dan 8) dampak terhadap pendapatan pemerintah.

\section{Pariwisata dan Kesempatan Berusaha atau Kerja}

Menurut BPS dalam Tando (1992), peluang usaha dan kerja dapat dibedakan atas usaha formal dan informal. Usaha informal adalah usaha tradisional yang lokasinya tidak tetap, tidak memakai bangunan dan jam kerja yang tidak teratur, mencakup usaha sendiri dan usaha dengan bantuan keluarga. Usaha formal merupakan usaha yang lokasinya tetap, menggunakan bangunan dan jam kerja yang teratur serta mencakup usaha dengan buruh tetap atau karyawan. Kegiatan informal merupakan kegiatan yang padat karya, tingkat produktifitas rendah, pelanggan yang sedikit, tingkat pendidikan formal yang rendah, penggunaan teknologi menengah, sebagian pekerja keluarga, mudah keluar masuk usaha, serta kurang dukungan dan pengakuan dari pemerintah. Breman dalam Tando (1992) memberikan batasan usaha formal sebagai semua pekerja yang bergaji bulanan atau harian dalam suatu pekerjaan yang permanen dan meliputi sejumlah pekerjaan yang saling berhubungan serta terorganisir dengan baik dan dilindungi badan hukum resmi.

BPS dalam Tando (1992) mengungkapkan bahwa penggunaan peluang usaha dan kerja dipengaruhi oleh faktor individu, yaitu pendidikan, jenis kelamin, status perkawinan dan umur. Soentoro (1983) dalam Tando (1992) menjelaskan bahwa seseorang yang mempunyai tingkat pendidikan rendah akan menempati sektor informal sedangkan yang berpendidikan agak tinggi cenderung memilih pekerjaan di sektor formal. Usaha formal pariwisata umumnya membutuhkan tenaga kerja dan berhubungan dengan pelayanan terhadap wisatawan (usaha penjualan jasa), sehingga sikap yang dibutuhkan dalam usaha pariwisata umumnya dimiliki oleh perempuan. Status perkawinan juga turut mempengaruhi di mana perempuan yang sudah menikah umumnya akan memanfaatkan peluang usaha yang tidak bertentangan dengan peran mereka sebagai ibu. Mereka yang sudah janda mempunyai kecenderungan tinggi untuk ber-partisipasi dalam usaha atau kerja karena kesempatan mereka relatif lebih longgar baik alasan biologis, psikologis, dan ekonomis. Motivasi memasuki lapangan kerja juga menentukan jenis pekerjaan yang ditekuni. Mereka yang janda cenderung memilih pekerjaan di usaha formal pariwisata (karyawan hotel, restoran atau guide) atau usaha informal sebagai pedagang yang berusaha sendiri. Bagi perempuan yang sudah kawin akan memilih pekerjaan yang dikerjakan sambil memainkan peranan sebagai ibu, seperti berdagang asongan atau dengan bantuan keluarga. Bagi mereka yang belum kawin akan memilih pekerjaan yang dapat dikerjakan kapan dan di mana saja, seperti menjadi karyawan hotel, restoran dan lain-lain.

Perbedaan kemampuan yang dimiliki oleh setiap manusia dalam pertumbuhan juga menyebabkan perbedaan jenis pekerjaan yang dipilih. Pemanfaat peluang usaha dan kerja yang tergolong dalam kelompok umur muda umumnya memilih pekerjaan yang menuntut kekuatan otot, seperti building, kitchen dan lain-lain. Pemanfaat peluang usaha dan kerja yang berumur menengah akan memilih pekerjaan yang bukan hanya menuntut kekuatan otot melainkan juga pertimbangan yang matang, seperti tour pada travel. Sebaliknya pemanfaat peluang usaha dan kerja yang berumur tua umumnya tidak dapat mengerjakan pekerjaan otot sehingga pekerjaan yang dipilih umumnya, seperti perdagangan, dan usaha lainnya pada usaha informal. 
Terdapat empat macam keterkaitan yang penting secara ekonomis berkenaan dengan pengembangan industri pariwisata di suatu daerah, yaitu keterkaitan produksi, konsumsi, modal dan tenaga kerja (Sadono et al., 1992). Keterkaitan produksi berlangsung dalam bentuk kerja sama pertukaran atau pemasokan faktor input produksi antara usaha industri skala besar dan formal dengan usaha-usaha masyarakat skala kecil. Jalinan ini terdapat pula pada aspek permodalan, usaha ekonomi skala kecil didorong melalui permodalan dengan skala usaha besar agar dapat tumbuh. Industri pariwisata yang tumbuh nantinya akan memberikan efek penyebarluasan penciptaan kesempatan kerja. Kunjungan wisatawan ke suatu daerah tujuan wisata akan membelanjakan sebagian atau seluruh uang mereka kepada produk atau jasa perdagangan yang ditawarkan masyarakat setempat. Aliran uang ini sebagian akan diterima oleh tenaga kerja dan juga pengusaha yang memasok barang dagangan di daerah tujuan wisata. Hal tersebut menunjukkan bahwa pariwisata mampu menciptakan kesempatan kerja sekaligus menciptakan peluang pendapatan. Adanya peluang usaha dan kerja dalam sektor pariwisata tidak terlepas dengan kebutuhan lokasi untuk berusaha. Tidak jarang lokasilokasi yang dianggap strategis telah menjadi incaran bagi para pemilik padat modal untuk dibeli dan digunakan untuk berusaha. Investor yang masuk dapat saja menyingkirkan banyak usaha di sektor informal terutama mereka yang terlebih dahulu berusaha di daerah tersebut.

\section{Wilayah Pesisir}

Menurut Soegiarto (1976) dalam Dahuri et al. (1996) mendefinisikan wilayah pesisir sebagai daerah pertemuan antara darat dan laut; ke arah darat wilayah pesisir, meliputi bagian daratan, baik kering maupun terendam air, yang masih dipengaruhi sifat-sifat laut seperti pasang surut, angin laut, dan perembesan air asin, sedangkan ke arah laut wilayah pesisir wilayah laut mencakup bagian laut yang masih dipengaruhi oleh proses-proses alami yang terjadi di darat, seperti sedimentasi dan aliran air tawar, maupun yang disebabkan oleh kegiatan manusia di darat seperti penggundulan hutan dan pencemaran. Definisi tersebut memberikan suatu pengertian bahwa ekosistem pesisir merupakan ekosistem yang dinamis dan mempunyai kekayaan habitat yang beragam. Dahuri et al. (1996) juga menjelaskan bahwa pada dasarnya wilayah pesisir secara keseluruhan memiliki berbagai fungsi dan manfaat bagi manusia diantaranya adalah penyedia sumber daya alam hayati, penyedia sumber daya alam nonhayati, penyedia energi, sarana transportasi, rekreasi dan pariwisata, pengatur iklim dan lingkungan hidup, penampung limbah, sumber plasma nutfah, pemukiman, kawasan industri serta pertahanan dan keamanan.

\section{Masyarakat Pesisir}

Masyarakat pesisir adalah sekumpulan masyarakat yang hidup bersama-sama mendiami wilayah pesisir membentuk dan memiliki kebudayaan yang khas yang terkait dengan ketergantungannya pada pemanfaatan sumber daya pesisir (Satria, 2004 dalam Satria, 2009). Masyarakat pesisir tidak saja nelayan tetapi juga terdapat pembudidaya ikan, pengolah ikan, pedagang ikan dan lainnya. Dahuri et al. (1996) menyatakan bahwa permasalahan yang dihadapi masyarakat pesisir antara lain terbatasnya sarana pelayanan dasar, kondisi lingkungan yang kurang terpelihara sehingga kurang memenuhi persyaratan kesehatan, air bersih dan sanitasi yang jauh dari mencukupi, keadaan perumahan yang umumnya jauh dari layak huni, keterampilan penduduk yang umumnya terbatas pada masalah penangkapan ikan sehingga kurang mendukung diversifikasi kegiatan, pendapatan penduduk rendah, pendidikan dan pengetahuan masyarakat yang umunya rendah, dan umumnya masih tradisional terbatas pada satu produk saja (ikan).

Dahuri et al. (1996) menjelaskan karakteristik masyarakat pesisir secara ekonomi memiliki mata pencaharian tradisional yang kegiatan utamanya di dominasi oleh usaha perikanan dengan tingkat pendapatan yang masih rendah sehingga berada pada garis kemiskinan. Kondisi sosial dicirikan dengan tingkat pendidikan yang masih rendah dengan ketergantungan hidup dari sumber-sumber perikanan di laut sehingga kurang mendukung diversifikasi usaha. Penyediaan sarana pelayanan dasar, seperti jalan, air bersih, sanitasi dan persampahan terbatas dan tidak mencukupi sehingga lingkungan pemukiman masyarakat pesisir jauh dari layak huni (kumuh).

Satria (2002) menjelaskan karakteristik masyarakat pesisir berbeda dengan karakteristik masyarakat agraris seiring dengan perbedaan karakteristik sumber daya yang dihadapi. Masyarakat agraris menghadapi sumber daya yang terkontrol berupa pengelolaan lahan untuk produksi suatu komunitas dengan output yang relatif dapat diprediksi. Sebaliknya nelayan menghadapi sumber daya yang bersifat open access di mana nelayan harus berpindah-pindah untuk memperoleh hasil yang maksimal. Kondisi tersebut menyebabkan masyarakat nelayan memiliki karakteristik yang keras, tegas dan terbuka. Dalam penelitian Sulaksmi (2007) menunjukkan bahwa peran masyarakat pesisir dalam pariwisata umumnya adalah menyediakan penyewaan penginapan, penyewaan perahu dan alat menyelam, menjual souvenir, menjual makanan, membuka rumah makan dan menjadi pemandu wisata.

\section{Stratifikasi Sosial}

Soekanto (1990) menjelaskan bahwa stratifikasi sosial merupakan pembedaan posisi seseorang atau suatu kelompok dalam kedudukan yang berbeda-beda secara vertikal. Menurut Sunarto (1993), stratifikasi sosial merupakan pembedaan anggota masyarakat berdasarkan status yang dimilikinya. Ukuran yang biasa digunakan untuk menggolongkan anggota masyarakat ke dalam suatu lapisan menurut Soekanto (1990) adalah 1) ukuran kekayaan, di mana lapisan teratas biasanya yang memiliki kekayaan yang paling banyak. Kekayaan disini bisa berbentuk rumah, kendaraan dan pakaian; 2) ukuran 
kekuasaan, lapisan teratas adalah yang paling memiliki kekuasaan atau wewenang terbesa; 3) ukuran kehormatan, di mana orang-orang yang paling dihormati dan disegani berada di lapisan teratas; 4) ukuran ilmu pengetahuan, dipakai oleh masyarakat yang menghargai ilmu pengetahuan. Kadang-kadang berakibat negatif karena yang dihargai adalah gelarnya bukan ilmu yang dimilikinya.

\section{Konversi Lahan}

Konversi lahan merupakan suatu proses perubahan penggunaan lahan oleh manusia dari penggunaan tertentu menjadi penggunaan lain yang dapat bersifat sementara dan permanen (Maftuchah, 2005 dalam Lestari, 2011). Kegiatan konversi lahan memiliki beragam pola tertentu tergantung pada kebutuhan dari usaha konversi lahan itu sendiri. Pola konversi lahan bila ditinjau berdasarkan aspek pelaku konversi menurut Soemaryanto et al. (2001) dalam Lestari (2011) dibedakan menjadi dua, yaitu:

1. alih fungsi secara langsung oleh pemilik lahan yang bersangkutan. Lazimnya, motif tindakan ada tiga, yaitu a) untuk pemenuhan kebutuhan akan tempat tinggal; b) dalam rangka meningkatkan pendapatan melalui alih usaha; dan c) kombinasi dari poin a) dan b), seperti untuk membangun rumah tinggal yang sekaligus dijadikan tempat usaha. Pola konversi seperti ini terjadi di sembarang tempat, kecil-kecil dan tersebar. Dampak konversi terhadap eksistensi lahan sekitarnya baru significant untuk jangka waktu lama;

2. alih fungsi yang diawali dengan alih penguasaan. Pemilik menjual kepada pihak lain yang akan memanfaatkannya untuk usaha nonsawah atau kepada makelar. Secara empiris, alih fungsi lahan melalui cara ini terjadi dalam hamparan yang lebih luas, terkonsentrasi dan umumnya berkorelasi positif dengan proses urbanisasi (pengkotaan). Dampak konversi terhadap eksistensi lahan sekitarnya berlangsung cepat dan nyata.

\section{Kerangka Pemikiran}

Sebagai negara kepulauan terbesar dengan garis pantai sepanjang $95.181 \mathrm{~km}$, Indonesia memiliki potensi sumber daya yang dapat memberikan peluang terhadap penciptaan bentuk pemanfaatan kawasan pesisir, seperti budidaya perikanan, kawasan konservasi, pemukiman dan pariwisata. Salah satu kawasan pesisir yang mempunyai potensi sumber daya dan dapat mendukung kegiatan pariwisata adalah Pulau Pramuka. Hadirnya kegiatan pariwisata akan menyebabkan adanya permintaan sarana dan prasarana yang dibutuhkan oleh wisatawan, seperti penginapan, rumah makan, transportasi, perdagangan, dan jasa. Kebutuhan-kebutuhan tersebut merupakan peluang usaha atau kerja terutama bagi masyarakat di kawasan objek wisata. Bentuk peluang usaha dan kerja dapat dibedakan berdasarkan sifatnya (formal dan informal), berdasarkan jenis kegiatan (penginapan, rumah makan, transportasi, perdagangan, jasa) serta berdasarkan pola kegiatan (kegiatan yang dilakukan setiap hari atau kegiatan yang hanya dilakukan di akhir pekan, liburan atau musim kunjungan wisatawan). Dalam menggunakan peluang usaha dan kerja tersebut, masyarakat yang bekerja atau berusaha diduga memiliki karakteristik individu, seperti asal penduduk, tingkat pendidikan, jenis kelamin, umur, dan status perkawinan. Pemanfaatan peluang usaha dan kerja juga dapat mempengaruhi pendapatan masyarakat yang memanfaatkan peluang tersebut yang dapat dilihat dari rata-rata pendapatan usaha atau kerja.

Selain itu, adanya peluang usaha dan kerja dapat memunculkan suatu keterkaitan antara sektor pertanian dan luar pertanian yang dilihat dari supply atau penyediaan bahan baku produksi (bahan pangan) dan pola penggunaan hasil (surplus atau keuntungan) usaha atau kerja. Pemanfaatan peluang usaha dan kerja seringkali terkait dengan ketersediaan lokasi yang dapat mempertemukan kebutuhan wisatawan (konsumen) dengan pengusaha (produsen), bahkan tidak jarang beberapa lokasi yang dianggap strategis telah menjadi incaran para investor dari luar pulau. Adanya pemanfaatan peluang usaha dan kerja dapat berpengaruh terhadap alih sumber daya dari milik penduduk lokal menjadi milik pendatang atau investor asing. Peralihan sumber daya ini dapat dilihat dari sejauh mana terjadi alih kepemilikan atau pembelian sumber daya (lahan) dari masyarakat lokal ke pendatang dan kebijakan pemerintah mengenai sumber daya (lahan) di tempat pariwisata. Bagan kerangka pemikiran ditunjukkan dalam Gambar 1.

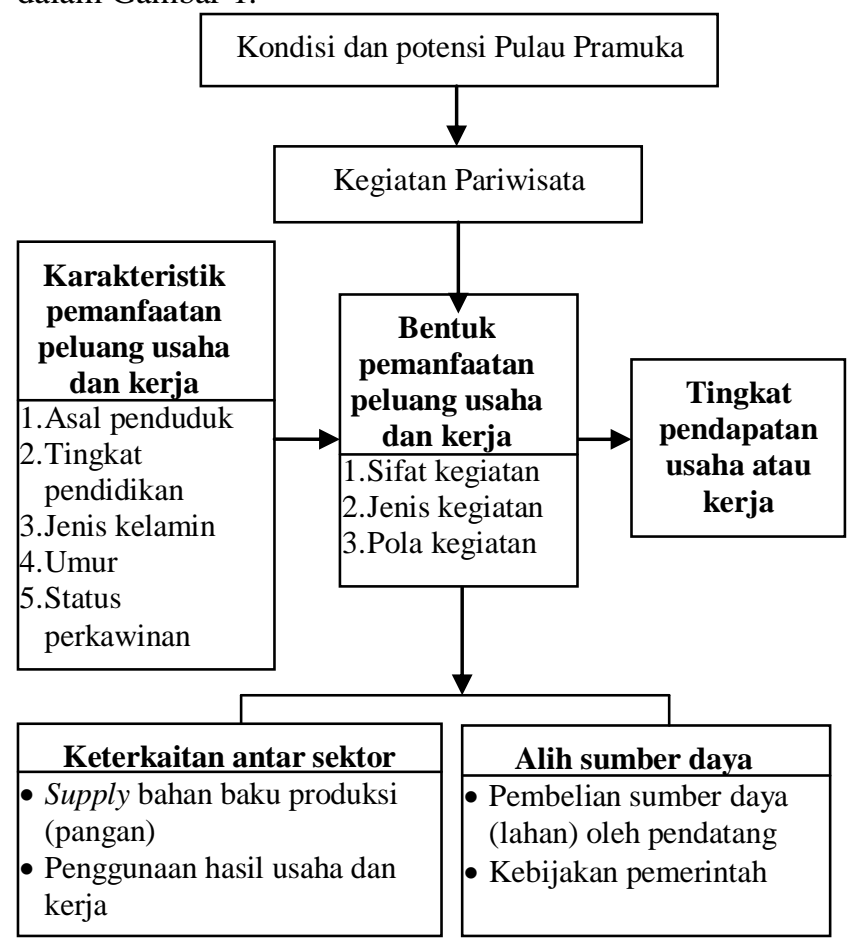

Gambar 1. Bagan Kerangka Pemikiran

\section{Hipotesis Pengarah}

Berdasarkan kerangka pemikiran di atas, maka disusun hipotesis pengarah sebagai berikut: 
1. adanya kegiatan pariwisata akan mendorong masyarakat untuk memanfaatkan peluang usaha dan kerja yang ada, seperti dalam usaha penginapan, rumah makan, perdagangan, transportasi dan jasa di mana pemanfaat peluang usaha dan kerja tersebut memiliki karakteristik tertentu berdasarkan asal penduduk, tingkat pendidikan, jenis kelamin, umur dan status perkawinan;

2. adanya kegiatan pariwisata mengakibatkan munculnya peluang usaha dan kerja di mana bentuk pemanfaatan peluang usaha dan kerja di pariwisata akan dapat menyebabkan peluang pendapatan usaha atau kerja yang berbeda pada setiap pelaku usaha atau kerja tersebut;

3. adanya kegiatan pariwisata mengakibatkan munculnya peluang usaha dan kerja di mana bentuk pemanfaatan peluang tersebut dapat menyebabkan peningkatan permintaan terhadap hasil-hasil pertanian, seperti perikanan baik dari sektor penginapan, rumah makan, transportasi, perdagangan maupun jasa. Adanya kegiatan pariwisata mengakibatkan munculnya peluang usaha dan kerja di mana bentuk pemanfaatan peluang tersebut dapat menyebabkan hasil usaha atau kerja berupa keuntungan usaha atau kerja, di mana keuntungan tersebut dapat digunakan untuk membiayai investasi di bidang pariwisata maupun di bidang lainnya;

4. adanya kegiatan pariwisata mengakibatkan munculnya peluang usaha dan kerja di mana bentuk pemanfaatan peluang tersebut memerlukan tempat atau lokasi yang dapat mempertemukan kebutuhan wisatawan dengan pengusaha. Lokasi yang dianggap strategis memungkinkan adanya intervensi dari pihak luar yang bermodal kuat (pendatang) untuk membeli lahan tersebut sehingga dapat terjadi alih sumber daya (lahan) dari masyarakat lokal ke masyarakat pendatang (investor luar). Adanya alih sumber daya (lahan) tidak terlepas dari kebijakan yang mengatur hal tersebut, di mana kebijakan tersebut bisa saja mendukung atau membatasi laju konversi (pengalihan) lahan.

\section{PENDEKATAN LAPANG}

\section{Lokasi dan Waktu Penelitian}

Penelitian ini dilakukan di Pulau Pramuka, Kelurahan Pulau Panggang, Kecamatan Kepulauan Seribu Utara, Kabupaten Administrasi Kepulauan Seribu, DKI Jakarta. Pemilihan lokasi dilakukan secara sengaja (purposive) didasarkan pada beberapa alasan, yaitu 1) penduduk Pulau Pramuka terdiri dari masyarakat desa pesisir dan dipengaruhi oleh aktivitas wisata; 2) Pulau Pramuka merupakan pusat Kabupaten Administrasi Kepulauan Seribu yang memiliki fasilitas terlengkap dibandingkan dengan pulau lainnya sehingga banyak wisatawan yang berkunjung ke pulau ini; 3) Pulau Pramuka merupakan salah satu tempat tujuan favorit serta bukan pulau yang dimiliki oleh pihak swasta sehingga memberi peluang bagi masyarakat untuk terlibat berusaha atau membuka lapangan kerja di sektor pariwisata. Kegiatan pengumpulan data primer dan sekunder dilakukan selama satu bulan dengan rentang pada bulan April-Mei 2011 dengan kegiatan pengolahan data, analisis data serta penulisan dilakukan pada rentang bulan Juni-Juli 2011.

\section{Teknik Pengumpulan Data}

Metode yang digunakan dalam penelitian ini adalah metode kualitatif yang didukung oleh metode kuantitatif sehingga penelitian ini merupakan penelitian deskriptif dengan didukung oleh pendekatan metode survei. Data yang digunakan dalam penelitian ini meliputi data primer dan data sekunder. Data primer diperoleh dari wawancara kuesioner dengan responden dan wawancara mendalam dengan informan. Data sekunder merupakan data yang dikumpulkan oleh pihak lain dan sudah diolah oleh pihak lain tersebut sehingga sumber data sekunder dapat diperoleh melalui kantor Kelurahan Pulau Panggang, Balai Taman Nasional Laut Kepulauan Seribu, Suku Dinas Pariwisata dan Kebudayaan Kepulauan Seribu, hasil penelitian sebelumnya serta dokumen-dokumen dan dinas-dinas lainnya yang terkait. Data sekunder yang dibutuhkan, seperti data pola kunjungan wisata di Kepulauan Seribu, profil Pulau Pramuka dan Kelurahan Pulau Panggang, profil Taman Nasional Laut Kepulauan Seribu, serta data-data yang terkait dengan peluang usaha dan kerja pariwisata di Pulau Pramuka.

Populasi pada penelitian ini adalah masyarakat yang bermatapencaharian di sektor yang berkaitan dengan pariwisata di Pulau Pramuka. Unit analisis pada penelitian ini adalah individu yang terlibat dalam usaha atau kerja karena adanya pariwisata baik sebagai pengusaha, karyawan tetap, maupun pekerja keluarga. Responden merupakan pihak yang memberi keterangan mengenai dirinya. Bila melihat kondisi lapang, jumlah antara pengusaha di sektor formal dan pengusaha di sektor informal menurut jenis kegiatan (penginapan, rumah makan, pedagang, transportasi, dan jasa) tidaklah berimbang, di mana ada beberapa pengusaha formal yang jumlahnya sangatlah sedikit dibandingkan usaha informal. Oleh karena itu, peneliti menggunakan dua metode pengambilan responden dalam penelitian ini, yaitu secara purposive dan secara acak berstrata (stratified random sampling) agar masing-masing profil usaha dapat terwakili.

Penentuan responden secara purposive (sengaja) dilakukan untuk beberapa jenis kegiatan (terutama penginapan, rumah makan, dan jasa) yang masuk dalam kegiatan formal (memiliki SIUK) mengingat jumlah usaha formal tersebut sangatlah sedikit. Jumlah responden yang diambil secara purposive adalah tiga responden untuk homestay, satu responden untuk restoran, dan dua responden untuk jasa dengan rincian satu responden catering dan satu responden biro perjalanan (travel agent). Sebaliknya sisanya menggunakan metode penarikan responden secara acak berstrata berdasarkan jenis usaha (penginapan, 
rumah makan, transportasi, pedagang dan jasa). Hal ini dilakukan karena sifat populasi yang heterogen sehingga populasi yang bersangkutan harus dibagi-bagi ke dalam lapisan yang seragam untuk kemudian diambil sampel secara acak dari setiap lapisan (Singarimbun dan Effendi, 1989).

Rincian jumlah responden yang diambil secara acak adalah sektor penginapan sebanyak 12 responden, sektor rumah makan sebanyak empat responden, sektor transportasi sebanyak 13 responden, sektor pedagang sebanyak 14 responden, dan sektor jasa sebanyak 32 responden. Besarnya sampel yang diambil menggunakan metode tidak berimbang dengan berdasarkan pada pertimbangan stratum yang lebih seragam dapat diambil jumlah unsur sampel yang lebih kecil dibandingkan dengan stratum yang lebih tidak seragam. Dengan demikian, jumlah keseluruhan responden yang diambil dalam penelitian ini adalah 81 responden. Pemilihan jumlah responden berpedoman pada diperolehnya keterwakilan profil masingmasing jenis usaha.

Informan merupakan seorang dari anggota kelompok yang dapat berbicara mengenai kelompoknya. Pemilihan informan ditentukan dengan teknik snowball sampling (pengambilan sampel sistem bola salju). Teknik tersebut merupakan teknik di mana seorang subjek akan menunjukkan kepada peneliti subjek selanjutnya untuk diwawancarai. Jumlah informan dalam penelitian ini tidak dibatasi guna memperoleh gambaran informasi yang lengkap. Pencarian informan akan berhenti apabila tambahan informan sudah tidak lagi menghasilkan informasi baru (berada pada titik jenuh). Informan dalam penelitian ini adalah tokoh masyarakat, seperti pejabat Balai Taman Nasional Laut Kepulauan Seribu, ketua RT, Kepala Seksi Perekonomian Kelurahan Pulau Panggang dan masyarakat yang memiliki pengaruh kuat di daerahnya.

\section{Teknik Pengolahan dan Analisis Data}

Pengolahan data kualitatif dalam penelitian ini menggunakan konsep Miles dan Hubermas (1992) dalam Sitorus (1998), yaitu dengan melakukan tiga subproses analisis, meliputi reduksi data, penyajian data, dan pengambilan kesimpulan. Reduksi data adalah proses pemilihan, pemusatan perhatian pada penyederhanaan, pengabstrakan dan transformasi data kasar yang muncul dari catatan tertulis di lapangan. Penyajian data adalah penyusunan informasi yang memungkinkan adanya penarikan kesimpulan dan pengambilan tindakan, di mana penyajian data dapat berbentuk teks naratif ataupun matriks, bagan, grafik dan jaringan. Penarikan kesimpulan berupa pencatatan keteraturan pola-pola yang terjadi, penjelasan, konfigurasi yang mungkin, alur sebab-akibat dan proporsi. Selain itu, untuk mengurangi kemungkinan kesalahan yang terjadi dalam menginterpretasi data, digunakan metode triangulasi dengan menguji silang tiga sumber data, yaitu hasil wawancara, observasi dan studi literatur.
Data kuantitatif yang telah dikumpulkan diolah mengacu pada langkah-langkah pengolahan data dari Singarimbun dan Effendi (1989). Langkah pertama dengan memasukkan data ke dalam kartu atau file data. Langkah kedua dengan membuat tabel frekuensi dan langkah ketiga dengan mengoreksi kesalahan-kesalahan yang ditemui setelah membaca tabel frekuensi tersebut.

\section{GAMBARAN UMUM LOKASI PENELITIAN}

Wilayah pesisir dan laut di Kelurahan Pulau Panggang memiliki potensi besar untuk pengembangan wisata bahari. Hal ini didukung oleh letak Kepulauan Seribu yang sangat strategis, yaitu berada di sebuah teluk yang relatif aman dari pengaruh cuaca yang ekstrim. Daya tarik wisata di wilayah ini terutama mengandalkan keindahan terumbu karang serta panorama laut dan pantai. Kegiatankegiatan wisata bahari yang dapat dilakukan di wilayah ini antara lain menyelam (scuba diving), snorkeling, memancing, wisata pendidikan (seperti penanaman lamun dan mangrove, serta rehabilitasi karang, penyu sisik, dan elang bondol), berkemah, barbeque party dan lain-lain. Dinamika kehidupan masyarakat setempat juga dapat menjadi daya tarik bagi wisatawan, seperti kegiatan masyarakat sebagai nelayan, kegiatan home industry para ibu-ibu rumah tangga serta kegiatan anak-anak yang berenang di dermaga. Selain itu, berbagai jenis ikan dan hasil laut juga dapat menjadi komoditi yang dapat ditawarkan kepada para wisatawan.

Tabel 1. Jumlah Pengunjung Per Tahun di Kepulauan Seribu Tahun 2003-2009

\begin{tabular}{cccc}
\hline No. & Tahun & $\begin{array}{c}\text { Jumlah } \\
\text { pengunjung }\end{array}$ & Peningkatan \\
\hline 1. & 2003 & 1.000 & - \\
2. & 2004 & 915 & -85 \\
3. & 2005 & 1.739 & 824 \\
4. & 2006 & 712 & -1.027 \\
5. & 2007 & 2.127 & 1.415 \\
6. & 2008 & 7.527 & 5.400 \\
7. & 2009 & 14.300 & 6.773 \\
\hline
\end{tabular}

Data Taman Nasional Laut Kepulauan Seribu menunjukkan perkembangan jumlah wisatawan yang datang ke kawasan Taman Nasional dari tahun ke tahun cenderung meningkat. Hal ini dapat dilihat dari data kunjungan wisatawan tahun 2003 sampai 2009 yang ditunjukkan dalam Tabel 1. Berdasarkan data pada Tabel 1, dapat dilihat bahwa kunjungan wisatawan ke kawasan Taman Nasional terlihat fluktuatif dengan kecenderungan meningkat. Pada rentang tahun 2003 hingga 2006 jumlah pengunjung hanya berkisar pada angka seribu, baru pada tahun 2007 pengunjung mencapai angka dua ribu. Data pada tahun 2009 menunjukkan bahwa jumlah pengunjung meningkat drastis, yaitu sebanyak 14.300 jiwa, di mana jumlah kunjungan tersebut dua kali lebih banyak dari tahun 2008, yaitu sebanyak 7.527 jiwa. Data kunjungan 
tersebut diperoleh berdasarkan pengunjung yang memiliki Surat Izin Masuk Kawasan Konservasi (Simaksi).

Bila melihat data berdasarkan catatan Pemerintah Kabupaten Administrasi Kepulauan Seribu, kunjungan ke Pulau Seribu pada tahun 2009 mencapai 400.000 orang, sedangkan pada tahun 2010 berkisar 500.000-600.000 orang. Dugaan pada tahun ini (tahun 2011), rata-rata di setiap akhir pekan terdapat 5.000 orang pengunjung yang berkunjung ke pulau-pulau pemukiman, seperti Pulau Pramuka dan Pulau Tidung. Seksi Perekonomian Kelurahan Pulau Panggang mencatat bahwa jumlah wisatawan atau pelancong pada bulan Januari 2011 adalah sebanyak 6.360 jiwa dengan rincian wisatawan lokal sebanyak 6.179 orang dan wisatawan asing sebanyak 181 orang. Wisatawan yang umumnya datang ke Pulau Pramuka adalah wisatawan lokal yang berdomisili di sekitar wilayah Jabodetabek (Jakarta, Bogor, Depok, Tangerang, Bekasi).

\section{HASIL PENELITIAN}

\section{Bentuk dan Karakteristik Pemanfaat Peluang Usaha dan Kerja Pariwisata}

Sejak adanya kebijakan peningkatan Kecamatan Kepulauan Seribu menjadi Kabupaten Administrasi Kepulauan Seribu pada tahun 2011 dan ibu kota kabupaten ditempatkan di Pulau Pramuka, maka pada tahun-tahun selanjutnya banyak fasilitas yang mulai dibangun di pulau ini. Tata tempat tinggal dan sanitasi di Pulau Pramuka juga tergolong cukup baik dibandingkan pulau pemukiman lainnya sehingga dapat mendukung kegiatan pariwisata di pulau ini. Dengan segala fasilitas yang dapat mendukung suatu kegiatan pariwisata dan adanya potensi sumber daya pesisir yang dapat dijadikan objek wisata, maka Pulau Pramuka mulai berkembang sebagai pulau wisata berbasis masyarakat. Kegiatan wisata di pulau ini juga tidak terlepas dari adanya program-program terkait dengan pariwisata yang dilakukan oleh berbagai pemangku kepentingan (stakeholder), seperti Pemerintah Daerah Kabupaten Administrasi Kepulauan Seribu, Taman Nasional Laut Kepulauan Seribu, LSM seperti Yayasan Terangi, serta pemangku kepentingan (stakeholder) lainnya.

Hadirnya sektor pariwisata di Pulau Pramuka telah menciptakan peluang usaha dan kerja di Pulau Pramuka, seperti dalam usaha homestay, perdagangan, rumah makan, transportasi dan jasa. Usaha homestay merupakan usaha dengan tingkat pertumbuhan yang tergolong tinggi, di mana dalam kurun waktu enam tahun semenjak tahun 2005 tercatat setiap tahunnya berdiri sekitar sembilan penginapan. Sifat kegiatan usaha pariwisata di Pulau Pramuka dominan pada sifat kegiatan informal $(73 \%) \mathrm{di}$ mana usaha belum dikelola secara profesional dan terutama menggunakan tenaga kerja keluarga sendiri. Pola kegiatan usaha dan kerja pariwisata dominan dilakukan setiap hari (79\%), meskipun kunjungan wisatawan umumnya ramai pada akhir pekan.
Alasan yang melatarbelakangi pemanfaat peluang usaha dan kerja pariwisata di Pulau Pramuka diantaranya adalah melakukan usaha dan kerja di pariwisata dengan latar belakang subsistensi $(60 \%)$, yaitu sebagai pekerjaan yang diandalkan untuk memenuhi kebutuhan hidup mereka serta sebagai bentuk investasi dan akumulasi keuntungan (40\%). Beberapa pekerja atau pengusaha di pariwisata melakukan investasi atau diversifikasi usaha ke sektor pariwisata dengan alasan karena prospek usaha di sektor ini cukup menguntungkan sehingga dapat diandalkan untuk menambah penghasilan. Faktor-faktor yang mendorong masyarakat di Pulau Pramuka memanfaatkan peluang usaha dan kerja di pariwisata diantaranya adalah meningkatnya jumlah wisatawan yang memerlukan pelayanan akan kegiatan wisata, adanya potensi sumber daya alam yang mendukung kegiatan pariwisata di pulau ini, dukungan berbagai pemangku kepentingan (stakeholder), seperti dalam bantuan permodalan, promosi wisata, dan pelatihan manajemen usaha sehingga masyarakat setempat dapat turut memanfaatkan peluang usaha dan kerja di pariwisata, sektor pariwisata mudah dimasuki terutama pada sektor usaha informal, serta dapat dijadikan alternatif mata pencaharian selain di sektor perikanan.

Karakteristik pemanfaat peluang usaha dan kerja pariwisata di Pulau Pramuka diantaranya adalah usaha dan kerja pariwisata lebih banyak dimanfaatkan oleh penduduk asli $(63 \%)$ dibandingkan penduduk pendatang. Pendatang yang memanfaatkan peluang usaha dan kerja cenderung masuk pada kegiatan usaha perdagangan. Pemanfaat peluang usaha dan kerja pariwisata dominan pada kategori tingkat pendidikan tinggi, yaitu lulusan pendidikan SMA maupun perguruan tinggi $(65,4 \%)$, namun pada sektor perdagangan terlihat dominan pada tingkat pendidikan sedang (tamatan SMP maupun SD). Pemanfaat peluang usaha dan kerja pariwisata di Pulau Pramuka dominan dilakukan oleh laki-laki (74\%). Hal ini karena cukup banyak kepala rumah tangga yang berprofesi di sektor pariwisata. Usaha dan kerja pariwisata di Pulau Pramuka dapat dimasuki oleh seluruh kategori umur. Pada jenis kegiatan pedagang, rumah makan dan homestay, cukup banyak pemanfaat peluang usaha dan kerja yang berumur lebih dari 40 tahun. Hal ini dimungkinkan karena usaha-usaha pada sektor tersebut tidak memerlukan kekuatan fisik dan mampu dimasuki bagi mereka yang telah pensiun. Sebaliknya pada usaha transportasi dan jasa, pemanfaat peluang usaha dan kerja lebih banyak pada rentang usia 31-40 tahun. Hal ini dimungkinkan karena beberapa usaha tersebut membutuhkan kekuatan fisik dan pertimbangan yang matang, seperti mengendarai kapal. Selain itu, usaha dan kerja pariwisata di Pulau Pramuka dominan dilakukan oleh mereka yang berstatus kawin $(85,2 \%)$. Bila dilihat secara stratifikasi sosial, pemanfaat peluang usaha dan kerja di sektor pariwisata cenderung berada pada strata rendah dan menengah. 


\section{Tingkat Pendapatan Usaha dan Kerja Pariwisata di Pulau Pramuka}

Semenjak Pulau Pramuka berkembang menjadi pulau wisata pemukiman, telah terjadi beberapa perubahan, seperti Pulau Pramuka dikenal oleh masyarakat luas, wawasan orang pulau meningkat, dan munculnya sumber penghasilan tambahan meskipun kegiatan pariwisata masih bersifat siklikal. Jumlah dan persentase responden berdasarkan tingkat pendapatan usaha pariwisata di Pulau Pramuka disajikan pada Tabel 2.

Tabel 2. Jumlah dan Persentase Responden Berdasarkan Tingkat Pendapatan Usaha Pariwisata di Pulau Pramuka Tahun 2011

\begin{tabular}{lcc}
\hline \multicolumn{1}{c}{ Tingkat pendapatan } & Jumlah & Persen \\
\hline Tinggi ( Pendapatan > Rp33.380.000,00 ) & 3 & 3,7 \\
Sedang ( Rp16.620.000,00 < Pendapatan $\leq$ & 1 & 1,2 \\
Rp33.380.000,00) & & \\
Rendah ( Rp140.000,00 $\leq$ Pendapatan $\leq$ & 77 & 95,0 \\
Rp16.620.000,00) & & \\
Total & 81 & 100,0 \\
\hline
\end{tabular}

Berdasarkan data pada Tabel 2, dapat dilihat bahwa hanya terdapat tiga usaha yang tergolong sebagai tingkat pendapatan tinggi di mana pendapatan tersebut lebih dari Rp33.380.000,00. Usaha yang masuk ke dalam kategori tingkat pendapatan tinggi tersebut adalah biro perjalanan (travel agent), restoran dan homestay. Selain itu, terdapat dua usaha yang masuk ke dalam tingkat pendapatan sedang, yaitu homestay di mana keduanya merupakan homestay formal. Sebaliknya sebanyak 95\% usaha termasuk ke dalam tingkat pendapatan rendah. Rata-rata pendapatan di sektor pariwisata, yaitu sekitar Rp4.262.901,00/bulan dengan pendapatan tertinggi mencapai Rp50.000.000,00/bulan dan pendapatan terendah Rp140.000,00/bulan. Usaha dengan pendapatan tertinggi tersebut merupakan usaha biro perjalanan, sedangkan usaha dengan pendapatan terendah adalah usaha penyewaan kapal yang dilakukan oleh nelayan setempat.

Tingkat pendapatan di setiap jenis kegiatan memang dominan pada tingkat pendapatan rendah, namun pada sektor kegiatan homestay, rumah makan dan jasa terdapat dapat usaha yang masuk pada tingkat pendapatan tinggi dan sedang. Usaha-usaha yang tergolong ke dalam tingkat pendapatan tinggi tersebut dominan dilakukan oleh pendatang yang bermodal besar dan hanya ada satu usaha yang tergolong tingkat pendapatan tinggi yang dilakukan oleh penduduk asli, yaitu pada sektor jasa. Pemanfaat usaha dan kerja di pariwisata terdiri dari mereka yang berusaha dan kerja hanya di sektor wisata, usaha dan kerja utama di sektor wisata dengan pekerjaan sampingan di sektor lain, serta usaha dan kerja sampingan di sektor wisata dengan pekerjaan utama di sektor lain. Kontribusi pendapatan pariwisata terhadap pendapatan rumah tangga bagi mereka yang berusaha dan bekerja hanya di sektor wisata adalah $100 \%$. Hal ini karena mereka hanya mengandalkan usaha dan pekerjaan mereka di satu sektor saja. Kontribusi pendapatan pariwisata terhadap pendapatan rumah tangga bagi mereka yang menjadikan usaha dan kerja di sektor wisata sebagai pekerjaan sampingan dengan pekerjaan utama di sektor lain adalah rata-rata sebesar 49,9\%. Angka tersebut mencapai 50\% disebabkan beberapa pengusaha memiliki pekerjaan atau usaha sampingan ganda di sektor pariwisata sehingga pendapatan sampingan mereka bisa lebih besar daripada pendapatan utama mereka. Akan tetapi, pendapatan pada sektor pariwisata tergolong tidak menentu sehingga para pengusaha maupun pekerja tersebut tetap mengandalkan pendapatan dari pekerjaan utama mereka untuk memenuhi kebutuhan rumah tangga. Hal ini karena pekerjaan utama mereka memiliki penghasilan yang tetap setiap bulannya. Sebaliknya kontribusi pendapatan pariwisata terhadap pendapatan rumah tangga bagi mereka yang menjadikan usaha dan kerja di sektor wisata sebagai pekerjaan utama dengan pekerjaan sampingan di sektor lain adalah ratarata sebesar $72,1 \%$

Pemanfaat peluang usaha dan kerja pariwisata cenderung menjadikan usaha dan kerja pariwisata sebagai mata pencaharian tunggal (68\%). Sisanya $18 \%$ diantaranya menjadikan usaha dan kerja pariwisata sebagai pekerjaan utama dengan pekerjaan sampingan di sektor lain, dan $14 \%$ diantaranya menjadikan usaha dan kerja pariwisata sebagai pekerjaan sampingan dengan pekerjaan utama di sektor lain. Sebanyak 95\% pelaku usaha dan kerja pariwisata termasuk ke dalam tingkat pendapatan rendah. Hal ini dimungkinkan karena kunjungan wisatawan yang bersifat siklikal sehingga pendapatan di sektor wisata tidaklah menentu.

\section{Keterkaitan Antara Sektor Pertanian dan Luar Pertanian di Pulau Pramuka}

Munculnya usaha yang diakibatkan oleh adanya kegiatan pariwisata sering membutuhkan bahan baku produksi (terutama pangan) sehingga kegiatan usaha dapat berlangsung. Hadirnya sektor pariwisata di Pulau Pramuka baik secara langsung maupun tidak langsung turut meningkatkan permintaan terhadap produk-produk pangan dari sektor pertanian, perikanan, maupun peternakan. Sektor yang cukup dominan dan menjadi andalan di Pulau Pramuka adalah sektor perikanan. Dampak dari kehadiran pariwisata di Pulau Pramuka sejauh ini terlihat dari meningkatnya permintaan terhadap produk-produk perikanan baik untuk menu makanan seafood maupun untuk oleh-oleh para wisatawan. Hasil dari nelayan yang ada di Pulau Pramuka selain untuk dipasarkan ke luar daerah Kepulauan Seribu, juga untuk memasok kebutuhan masyarakat di Pulau Pramuka termasuk usaha di Pariwisata. Jenis tanah dan lahan yang terbatas di Pulau Pramuka menjadikan Pulau Pramuka tidak memungkinkan untuk ditanami tanaman pangan, seperti padi sawah bahkan untuk kegiatan ternak, seperti sapi dan kambing, sehingga untuk memenuhi kebutuhan 
pangan (selain dari sektor perikanan) penduduk Pulau Pramuka harus membelinya ke luar daerah Kepulauan Seribu.

Berdasarkan tempat memperoleh bahan pangan dan jenis kegiatan usaha pariwisata di Pulau Pramuka didapatkan bahwa pada sektor homestay seluruh usaha $(37,5 \%)$ mendapatkan bahan pangan dari dalam Pulau Pramuka. Bahan-bahan tersebut dibeli dari nelayan langsung, pemasok atau penjual sayur bakulan yang ada di Pulau Pramuka. Beberapa homestay informal juga cenderung bekerja sama dengan catering yang ada di Pulau Pramuka sehingga untuk memenuhi kebutuhan konsumsi tamu homestay, mereka akan memesan pada catering tersebut. Pada sektor rumah makan seluruh responden (12,5\%) mendapatkan bahan pangan baik dari dalam Pulau Pramuka maupun luar Kepulauan Seribu. Usaha rumah makan dan warung nasi umumnya memperoleh bahan baku pangan dengan memesan pada agen di dalam pulau. Agen tersebut nantinya akan berbelanja ke Pasar Muara Angke dan sekitarnya. Beberapa bahan juga dapat dibeli di warung sembako milik penduduk lokal. Namun untuk bahan seafood pengusaha dapat membeli dari penjual ikan segar atau memesan langsung pada nelayan di Pulau Pramuka. Restoran NRO memperoleh bahan seafood dari hasil budidaya ikan keramba milik perusahaan tersebut. Namun bahan-bahan lainnya dikirim dari luar Kepulauan Seribu, seperti sayuran, bumbu dapur, beras dan lainnya. Sebaliknya para pedagang warung sembako hampir semuanya mendapatkan bahan baku dari Pasar Muara Angke di daerah Jembatan Dua, termasuk bahan-bahan, seperti sayuran, beras, daging dan bumbu dapur. Umumnya pedagang warung sudah memiliki toko-toko langganan dan tidak jarang mengkredit barang-barang sembako untuk dijual di warungnya.

Pada sektor jasa catering, bahan baku didapatkan baik dari dalam Pulau Pramuka maupun dari luar Kepulauan Seribu (7,5\%). Bahan-bahan catering, seperti seafood dapat diperoleh di dalam pulau dengan memesan pada penjual ikan segar maupun langsung pada nelayan. Sebaliknya untuk mendapatkan sayur-sayuran, daging dan bumbu lainnya umumnya jasa catering memesan kepada agen maupun pedagang sayur bakulan yang ada di Pulau Pramuka. Meskipun demikian, ada beberapa usaha catering yang lebih memilih untuk berbelanja langsung ke pasar di luar Kepulauan Seribu.

Pada sektor pedagang, asal bahan baku (pangan) cukup beragam baik dari dalam Pulau Pramuka, sekitar Pulau Pramuka dan luar Kepulauan Seribu. Para pedagang kaki lima di Pulau Pramuka umumnya mendapatkan bahan baku di warung-warung yang berada di Pulau Pramuka, seperti sayuran, terigu dan sebagainya. Namun ada pula yang bekerja sama dengan agen (supplier) tertentu. Para pedagang umumnya memperoleh produk perikanan, seperti ikan segar dari nelayan-nelayan setempat atau di tempat pelelangan ikan, untuk kemudian dijual langsung maupun diolah menjadi produk-produk home industry, seperti kerupuk ikan, ikan asin, cumi asin, dodol rumput laut, manisan rumput laut dan sebagainya. Ada pula produk yang diperoleh dari sekitar Pulau Pramuka, seperti keripik sukun yang diperoleh dari Pulau Pari, serta ikan teri dan ikan asin dari Pulau Panggang. Beberapa pedagang ada pula yang memperoleh bahan baku dari luar Kepulauan Seribu, seperti penjual mie ayam yang mendapatkan mie khusus untuk mie ayam dari luar Kepulauan Seribu.

Berdasarkan pola penggunaan hasil usaha pariwisata di Pulau Pramuka sebanyak $62 \%$ pengusaha dan pekerja menggunakan hasil usaha untuk kebutuhan hidup seharihari dan tabungan. Sebanyak $32 \%$ pengusaha dan pekerja menggunakan hasil usaha untuk diinvestasikan kembali pada usaha pariwisata yang dijalankannya (termasuk melunasi hutang kredit usaha) dan hanya ada sebanyak dua persen yang menggunakan hasil usaha pariwisata untuk diinvestasikan pada usaha di luar sektor pariwisata. Sisanya sebanyak 4\% menggunakan hasil usaha untuk membeli rumah, perhiasan dan tanah. Lebih dari $60 \%$ responden menggunakan hasil usaha dan kerja di sektor pariwisata untuk memenuhi kebutuhan hidup rumah tangga mereka. Hal ini menunjukkan bahwa sektor pariwisata sangat diandalkan oleh penduduk (baik penduduk asli maupun pendatang) yang ada di Pulau Pramuka sebagai pendapatan utama maupun pendapatan tambahan bagi pendapatan rumah tangga mereka. Beberapa pengusaha yang menginvestasikan hasil usaha mereka untuk membangun usaha baru di sektor pariwisata memungkinkan adanya penyerapan tenaga kerja baru di sektor pariwisata. Beberapa pengusaha juga ada yang menggunakan hasil usaha tersebut untuk membeli perhiasan, rumah maupun tanah sebagai tabungan lain (selain dalam bentuk uang) bagi mereka.

\section{Alih Sumber Daya dalam Pemanfaatan Peluang Usaha dan Kerja}

Guna menunjang kegiatan usaha pariwisata, tentunya dibutuhkan suatu lokasi yang dapat mempertemukan kebutuhan antara wisatawan dengan sang pengusaha. Lokasi-lokasi yang cukup stratregis tentunya telah menjadi banyak incaran para pengusaha untuk mendirikan usaha di tempat tersebut, seperti untuk kegiatan usaha homestay dan rumah makan. Lokasi yang dianggap strategis juga biasanya merupakan lahan bagi para pedagang (usaha informal) untuk berjualan di lokasi tersebut. Lokasi-lokasi yang dianggap strategis di Pulau Pramuka diantaranya adalah lahan di depan dermaga tempat di mana para penumpang maupun wisatawan baru saja turun dari kapal, jalan disamping Rumah Sakit Umum Daerah (RSUD) Kabupaten Administrasi Kepulauan Seribu serta beberapa lokasi yang dapat langsung melihat keindahan laut maupun matahari terbit dan tenggelam. Jalan disamping RSUD merupakan lahan yang cukup strategis bagi para pedagang karena merupakan percabangan jalan dan dekat dengan homestayhomestay yang berada di sepanjang jalan dermaga. 
Berdasarkan status lahan usaha pariwisata di Pulau Pramuka sebanyak $78 \%$ pengusaha memiliki lahan dengan status milik pribadi baik dengan membeli tanah ke orang lain maupun tanah warisan dari keluarga sang pengusaha. Sisanya sebanyak $12 \%$ pengusaha memiliki lahan usaha dengan status sewa dengan sistem pembayaran per tahun, dan $10 \%$ pengusaha memiliki lahan usaha dengan status menumpang atau diberikan pinjaman tempat. Pada status lahan usaha milik pribadi dan meminjam, dominan dimiliki oleh penduduk asli. Sebaliknya pada status lahan usaha menyewa, dominan dimiliki oleh penduduk pendatang. Perbedaan yang cukup mencolok dalam hal kepemilikan lahan usaha antara penduduk asli dan pendatang terlihat pada status lahan usaha milik pribadi, di mana hanya sedikit pendatang yang memiliki lahan usaha dengan status lahan milik pribadi.

Faktor-faktor yang turut mendorong terjadinya pembelian tanah atau alih sumber daya baik oleh penduduk asli maupun pendatang adalah kunjungan wisatawan ke Pulau Pramuka yang cenderung meningkat beberapa tahun belakangan ini dan faktor pertambahan penduduk yang dengan sendirinya membuat penduduk (terutama penduduk lokal) membutuhkan lahan untuk tempat tinggal. Kunjungan wisatawan yang meningkat tersebut telah mendorong penduduk asli dan beberapa penduduk pendatang untuk membeli lahan untuk digunakan sebagai lahan usaha terutama membangun penginapan (homestay) baru. Dalam hal membangun homestay, tentunya dibutuhkan suatu lahan tempat bangunan homestay didirikan. Lahan yang digunakan untuk dibangun homestay beberapa ada yang merupakan tanah warisan keluarga, maupun lahan pribadi yang dibeli dari orang lain. Ada pula homestay yang awalnya merupakan rumah sang pengusaha yang kemudian dirubah menjadi sebuah penginapan atau lahan berusaha lainnya.

Penduduk Pulau Pramuka cenderung tidak ingin menjual tanah mereka meskipun ada pula pemilik tanah yang berminat untuk menjual tanah asalkan harga yang ditawar cukup tinggi. Sebab harga tanah di Pulau Pramuka saat ini melambung tinggi, sehingga tanah merupakan aset penting bagi mereka. Harga tanah yang melambung tinggi disebabkan oleh makin maraknya pembelian lahan untuk lahan usaha, seperti homestay, kontrakan maupun untuk dibangun rumah, sedangkan lahan kosong yang tersedia semakin terbatas jumlahnya. Para pemilik tanah juga tidak ingin menjual tanah karena ingin diwariskan kepada keluarga mereka. Berdasarkan pola konversi lahan menurut aspek pelaku konversi, dapat dikatakan bahwa pemanfaat peluang usaha dan kerja pariwisata di Pulau Pramuka dominan melakukan alih fungsi lahan secara langsung oleh pemilik lahan yang bersangkutan. Motif tindakan cenderung pada motif meningkatkan pendapatan melalui alih usaha dan motif kombinasi, yaitu dengan membangun tempat tinggal yang sekaligus dapat dijadikan tempat usaha. Sejauh ini hanya terdapat kebijakan dari Pemda setempat di mana zona di sepanjang pinggir pantai tidak boleh dibangun bangunan apapun karena digunakan untuk jalan lingkar pulau. Penduduk Pulau Pramuka tidak merasa terganggu dengan kebijakan tersebut. Hal ini karena jalan lingkar pulau membuat jalan di pulau menjadi tertata lebih rapi. Pemerintah setempat turut mendukung bila ada investor yang mau membeli lahan di pulau ini asalkan dapat memberi keuntungan bagi penduduk setempat.

\section{KESIMPULAN DAN SARAN}

\section{Kesimpulan}

Dari penelitian yang dilakukan di Pulau Pramuka dapat diperoleh beberapa kesimpulan, yaitu hadirnya sektor pariwisata di Pulau Pramuka telah menciptakan peluang usaha dan kerja bagi penduduk di Pulau Pramuka. Usaha tersebut diantaranya, seperti homestay, rumah makan, pedagang, transportasi dan jasa. Sifat kegiatan usaha pariwisata di Pulau Pramuka dominan pada sifat kegiatan informal, di mana usaha tidak memiliki surat izin dari pemerintah, pengelolaan secara sederhana dan menggunakan tenaga kerja keluarga. Pola kegiatan usaha pariwisata umumnya adalah setiap hari, meskipun ada pula usaha yang hanya buka di saat akhir pekan atau di saat kunjungan wisatawan tergolong ramai.

Karakteristik pemanfaat peluang usaha dan kerja pariwisata di Pulau Pramuka diantaranya adalah usaha dan kerja lebih banyak dimanfaatkan oleh penduduk asli, pemanfaat peluang usaha dan kerja pariwisata umumnya adalah mereka yang telah menamatkan pendidikan SMA maupun perguruan tinggi terutama pada usaha di sektor formal. Berdasarkan jenis kelamin, pemanfaat peluang usaha dan kerja pariwisata di Pulau Pramuka dominan dilakukan oleh laki-laki. Usaha dan kerja pariwisata di Pulau Pramuka dapat dimasuki oleh seluruh kategori umur dan berdasarkan status perkawinan, usaha dan kerja pariwisata di Pulau Pramuka dominan dilakukan oleh mereka yang telah berstatus kawin. Bila dilihat secara stratifikasi sosial, dapat dikatakan bahwa masyarakat yang memanfaatkan peluang usaha dan kerja di sektor pariwisata cenderung berada pada strata rendah dan menengah.

Pemanfaat peluang usaha dan kerja pariwisata dominan menjadikan usaha dan kerja tersebut sebagai pendapatan (mata pencaharian) tunggal bagi mereka. Meskipun demikian, ada beberapa yang menjadikan usaha pariwisata sebagai pekerjaan sampingan terutama bagi mereka yang bekerja sebagai PNS. Pendapatan pemanfaat usaha dan kerja pariwisata masih tergolong ke dala tingkat pendapatan rendah. Hal ini dimungkinkan karena kunjungan wisatawan yang bersifat siklikal sehingga pendapatan di sektor wisata tidaklah menentu. Namun di saat akhir pekan atau di musim kunjungan wisatawan yang cukup tinggi, seperti pada tahun baru, pendapatan para pengusaha dan pekerja pariwisata dapat meningkat drastis. Pendapatan yang cukup tergolong tinggi adalah pendapatan biro perjalanan dan usaha formal, seperti 
restoran dan homestay yang juga memerlukan modal yang cukup besar.

Keterkaitan antara sektor pertanian dan luar pertanian usaha pariwisata di Pulau Pramuka ditunjukkan dengan meningkatnya permintaan terhadap produk-produk di sektor perikanan yang ada di Pulau Pramuka terutama sebagai bahan baku bagi beberapa usaha, seperti rumah makan, perdagangan dan jasa catering. Produk-produk pertanian, seperti beras, sayuran, bumbu dapur serta produk peternakan, seperti daging didapatkan dari luar daerah Kepulauan Seribu. Alokasi penggunaan hasil usaha selain untuk kebutuhan sehari-hari dan biaya operasional usaha, beberapa ada yang digunakan untuk memperbesar usaha di sektor pariwisata maupun berusaha di sektor lain.

Sejauh ini alih sumber daya yang terjadi akibat adanya kegiatan pariwisata di Pulau Pramuka (terutama dalam hal pembelian tanah di Pulau Pramuka) cenderung dilakukan di antara penduduk asli Pulau Pramuka. Beberapa pendatang cenderung menyewa atau mengontrak lahan untuk kemudian dijadikan lahan berusaha ataupun tempat tinggal. Usaha di sektor pariwisata lainnya cenderung menggunakan rumah sendiri bahkan meminjam tempat untuk dijadikan lahan usaha. Berdasarkan pada pola konversi lahan menurut aspek pelaku konversi, pemanfaat peluang usaha dan kerja pariwisata di Pulau Pramuka dominan melakukan alih fungsi lahan secara langsung oleh pemilik lahan yang bersangkutan. Motif tindakan cenderung pada motif meningkatkan pendapatan melalui alih usaha dan motif kombinasi, yaitu dengan membangun tempat tinggal yang sekaligus dapat dijadikan tempat usaha. Sejauh ini tidak ada kebijakan yang mengatur pertanahan di Pulau Pramuka, hanya ada kebijakan Pemda yang melarang membangun bangunan di sekitar jalan lingkar pulau. Pemda sendiri mendukung bila seandainya ada investor luar yang mau berusaha di Pulau Pramuka selama usaha tersebut dapat menguntungkan warga setempat.

\section{Saran}

Kegiatan penelitian ini diharapkan dapat berguna bagi pihak-pihak yang terkait. Melalui hasil penelitian ini disarankan:

1. pemerintah disarankan untuk mendukung dan memfasilitasi penduduk lokal dalam mewujudkan "Pulau Wisata Pemukiman" di Pulau Pramuka, seperti melalui bantuan permodalan, pelatihan manajemen usaha dan keuangan serta menghidupkan paguyubanpaguyuban usaha yang ada di Pulau Pramuka. Hal ini disebabkan kegiatan usaha pariwisata sejauh ini merupakan alternatif mata pencaharian selain di sektor perikanan, sehingga partisipasi para penduduk lokal dalam sektor wisata perlu dipertahankan karena membawa pada pertumbuhan perekonomian di Pulau Pramuka. Pemerintah perlu melakukan sosialisasi dan memudahkan para pengusaha wisata di Pulau Pramuka yang ingin mendapatkan surat izin usaha;

2. perlu adanya kebijakan pemerintah dalam hal membatasi investor luar maupun pemodal besar yang masuk dan berusaha ke Pulau Pramuka terutama jika dapat mematikan usaha penduduk lokal yang umumnya terbatas oleh modal. Termasuk menyusun ulang kebijakan tarif kapal kerapu yang merupakan milik Sudin Perhubungan. Sebelum pariwisata berkembang dan kapal kerapu ada, kapal ojek tradisional Muara Angke sudah beroperasi lebih dulu. Bahkan kapalkapal ini juga telah berjasa membawa ribuan wisatawan ke Pulau Pramuka. Kehadiran kapal kerapu dengan tarif yang tidak berbeda jauh dengan tarif kapal ojek, telah menimbulkan persaingan dan kecemburuan bagi pengusaha kapal ojek di Muara Angke. Apalagi kapal kerapu baik dari segi desain dan mesin jauh lebih canggih dibandingkan kapal ojek tradisional serta mendapatkan subsidi dari pemerintah. Oleh karena itu, Pemerintah perlu mempertimbangkan kembali mengenai tarif Kapal Kerapu yang diterapkan;

3. perlu adanya perbaikan pelayanan bagi para wisatawan di Pulau Pramuka, seperti dukungan sarana mesin ATM sehingga memudahkan wisatawan dalam memperoleh uang tunai dengan cepat;

4. bagi kaum akademisi, perlu adanya penelitian lanjutan mengenai dampak pariwisata di Pulau Pramuka terutama pada aspek-aspek lain selain peluang usaha dan kerja di luar pertanian.

\section{DAFTAR PUSTAKA}

Dahuri, Rokhmin., Jacub Rais., Sapta P., Ginting., dan M. J. Sitepu. 1996. Pengelolaan Sumber Daya Wilayah Pesisir dan Lautan secara Terpadu. Jakarta : PT. Pradnya Paramita.

Karyono, A. Hari. 1997. Kepariwisataan. Jakarta: PT Gramedia Widiasarana Indonesia.

Lestari, Astri. 2011. Dampak Sosio-Ekonomis dan SosioEkologis Konversi Lahan (Studi Kasus: Desa Tugu Utara, Kecamatan Cisarua, Kabupaten Bogor). [Skripsi]. Bogor : Fakulas Ekologi Manusia, IPB.

Mardiyaningsih, Dyah Ita. 2003. Industri Pariwisata dan Dampaknya terhadap Kehidupan Sosial-Ekonomi Masyarakat Lokal.[Skripsi]. Bogor: Fakultas Pertanian, IPB.

Minullah. 1997. Perkembangan Pariwisata dan Pengaruhnya terhadap Pendapatan Masyarakat di Kabupaten Poso. Palu: Fakultas Ekonomi Universitas Tadulako.

Musanef. 1996. Manajemen Usaha Pariwisata di Indonesia. Jakarta : PT Toko Gunung Agung.

Pendit, Nyoman S. 2006. Ilmu Pariwisata. Jakarta : PT Pradnya Paramita. 
Pitana, I Gde dan Putu Gayatri. 2004. Sosiologi Pariwisata. Yogyakarta: Penerbit Andi.

Sadono, Dwi, Soeryo Adiwibowo, dan Arya $\mathrm{H}$. Dharmawan. 1992. Dampak Pariwisata terhadap Peluang Usaha dan Kerja Luar Pertanian di Pedesaan: Kasus di Daerah Wisata Pelabuhan Ratu, Sukabumi, Jawa Barat. Bogor : Pusat Studi Pembangunan-Lembaga Penelitian IPB.

Satria, Arif. 2002. Pengantar Sosiologi Masyarakat Pesisir. Jakarta : Pustaka Cidesendo.

2009. Pesisir dan Laut untuk Rakyat. Bogor : IPB Press.

Singarimbun, Masri dan Sofian Effendi. 1989. Metode Penelitian Survai. Jakarta: LP3ES.

Sitorus, M. T. Felix. 1998. Penelitian Kualitatif "Suatu Perkenalan". Bogor: Jurusan Ilmu-Ilmu Sosial dan Ekonomi Pertanian, Fakultas Pertanian IPB.

Soekanto, Soerjono. 1990. Sosiologi Suatu Pengantar. Jakarta : PT. Raja Grafindo Persada.

Sudirman, I Wayan., I Gusti A. K. Giantari., Ketut Nurcahya., Wayan Sudianing., dan Nyoman Sudiarta. 1991. Pengaruh Pariwisata terhadap Pemanfaatan Kerja Wanita dan Penciptaan Pendapatan di Desa Sanur. Bali : Fakultas Ekonomi Universitas Udayana.

Sulaksmi, Rita. 2007. Analisis Dampak Pariwisata terhadap Pendapatan dan Kesejahteraan Masyarakat Sekitar Kawasan Taman Wisata Alam Laut Pulau Weh Kota Sabang. [Tesis]. Bogor: Program Studi Ilmu-Ilmu Perencanaan Pembangunan Wilayah dan Perdesaan IPB.

Sunarto, Kamanto. 1993. Pengantar Sosiologi. Jakarta: Fakultas Ekonomi Universitas Indonesia.

Swarsi, I made Panca., I. B. Yuda Trigun., I. Gst. Made Sugiharta., I Wayan Namiartha., dan Tjok Istri Putri. 1996. Dampak Pengembangan Pariwisata terhadap Kehidupan Sosial Budaya Daerah Bali. Bali: Departemen Pendidikan dan Kebudayaan.

Tando, Samuel. 1992. Dampak Pengembangan Pariwisata terhadap Peluang Usaha atau Kerja Luar Pertanian: suatu pengamatan di Kelurahan Tikunna Malenong, Kecamatan Sanggalagi, Kabupaten Tana Toraja, Provinsi Sulawesi Selatan. [Tesis]. Bogor : Program Pasca Sarjana IPB.

Undang-Undang Nomor 10 Tahun 2009 Tentang Kepariwisataan.

Wijaya, Dewa Putu Mustika. 2007. Analisis Dampak Perkembangan Pariwisata terhadap Kondisi Sosial Ekonomi dan Budaya Masyarakat Pesisir Desa Gili Indah, Kecamatan Pemenang, Kabupaten Lombok
Barat, Provinsi Nusa Tenggara Barat. [Skripsi]. Bogor: Fakultas Perikanan dan Ilmu Kelautan IPB.

Windiyarti, Dara, Primus Gusman, dan Eusebio Da Costa. 1994. Dampak Pengembangan Pariwisata terhadap Kehidupan Sosial di Dearah Timor Timur. Timor Timur: Departemen Pendidikan dan Kebudayaan.

Yoeti, Oka A.1996. Pengantar Ilmu Pariwisata. Bandung: Penerbit Angkasa. 2008. Ekonomi Pariwisata. Jakarta: Buku Kompas. 
